\title{
Angle-count sampling method for estimating forest stand volume - a practical approach
}

\author{
Károly Rédei ${ }^{1}$ - Tamás Ábri ${ }^{1}$ - Fruzsina Szabó ${ }^{1}$ - Zsolt Keserü ${ }^{2}$ \\ ${ }^{1}$ University of Debrecen Faculty of Agricultural and Food Sciences and Environmental Management, Debrecen \\ ${ }^{2}$ National Agricultural Research and Innovation Centre - Forest Research Institute, Department of Plantation Forestry, Püspökladány \\ keseru.zsolt@naik.erti.hu
}

\begin{abstract}
SUMMARY
Point sampling, which is also known as angle-count sampling (ACS), can be considered an efficient way of estimating the basal area and volume of forest stands. It is possible to use it in forest management: providing more accurate estimates (precision <10\%) of site and stand characteristics needed for management planning. 20 black locust (Robinina pseudoacacia L.) stands were selected at final cutting age to determine the regeneration criteria based on their total volume. It was verified that at $P=5 \%$ there was no difference between the main volume values of stands indicated in the relevant forest plans as well as calculated by the ACS method.
\end{abstract}

Keywords: forest mensuration, sampling, basal area, volume

\section{INTRODUCTION}

The forest stand is defined as a group of trees occupying a specific area, which is sufficiently uniform in species composition, age arrangement and condition as to be distinguishable from the forest on adjoining areas. It represents the unit for which one and the same silvicultural treatment is prescribed. Quantitative information about stand or forest compartments, therefore, relates directly to silvicultural and management decisions. Stand measurements provide information about age, mean diameter, mean and top height, stand density, stand mixture and stand composition, volume and biomass, site index, site class or yield class, present and future growth, stand quality and vitality as well as yield (Bell and Dilworth, 1990; Laar and Akca, 2007; Veperdi, 2011).

Point (angle count) sampling is a method of selecting trees to be tallied on the basis of their sizes rather than by their frequency of occurrence. Sample points, somewhat analogous to plot centers, are located within a forested tract, and a simple prism or angle gauge that subtends a fixed angle of view is used to ,sight in" each diameter at breast height (dbh). Tree boles close enough to the observation point to completely fill the fixed sighting angle are tallied; stems too small or too far away are ignored. The resulting tree tally may be used to compute basal areas, volumes, or numbers of trees per unit area (Hunt and Baker, 1967; Barrett, 1969; Avery and Burkhart, 1994).

The probability of tallying a given tree depends on its cross-sectional area and the sighting angle used. The smaller the angle, the more stems will be included in the sample. Point sampling does not require direct measurements of either plot areas or tree diameters. A predetermined Basal Area Factor (BAF) is established in advance of sampling, and resulting tree tallies can be easily converted to basal area per unit area (Wensel et al., 1980; Oderwald, 1981).

The theory and technique of point sampling, which is also known as angle-count sampling, plotless sampling, Bitterlich's method, and relascope sampling, and is widely recognised as a breakthrough in forest mensuration, was developed by the Austrian forester Bitterlich, in 1948 (Bitterlich, 1948; Beers and Miller, 1964). In its original version, it was designed in estimate the basal area per hectare. Grosenbaugh (1958) extended the basic principle of point sampling and re-defined the method as PPS sampling (Probability Proportional to Size) (Bruce, 1955; Laar and Akca, 1997).

The main aim of our study is to demonstrate how to apply the angle-count sampling method in the practice for estimating black locust (Robinia pseudoacacia L.) stand volume. This method is used as a decision aid to determine the volume of black locust stands that can be regenerated from sprout (Rédei et al., 2012; Rédei, 2015).

\section{MATERIALS AND METHODS}

In the area of Nagykunsági Forest Enterprise (NEFAG), Hungary, 20 black locust (Robinia pseudoacacia L.) forest subcompartments (Figure 1) in final cutting stand age were selected in order to test the accuracy of the angle- count sampling method and to compare the given black locust volume data to that of indicating in the forest plans (Figure 1). In the latter, the determination of tree volume per hectare was done by yield table (Rédei, 1984). 


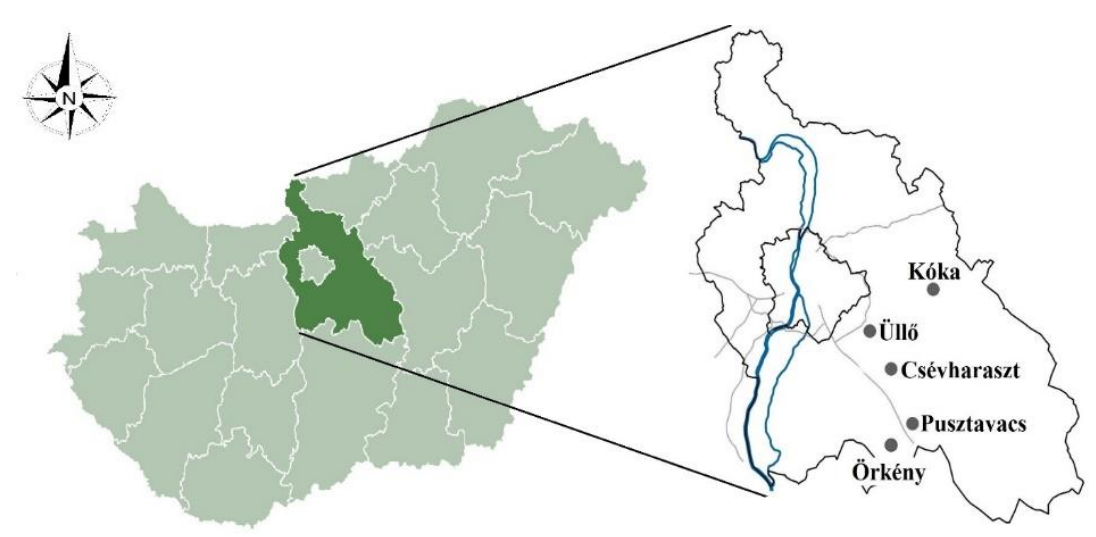

Point sampling estimates stand parameters from sample plots with imaginary plot boundaries. A critical angle is introduced, which defines the ratio between the diameter of a tree and its distance from the sampling point. For each of the trees surrounding the sampling point, a decision is made whether it is ,in" or ,out," i.e., whether it falls inside or outside the plot with its imaginary boundaries. The number of trees counted „in” is used to predict the stand parameter. A device with a fixed angle of view is used to sight the surrounding trees at breast height, in a $360^{\circ}$ sweep. All trees with an apparent dbh, which exceeds the angle of viewing, are tallied ,in”. The basal area per unit area $\left(\mathrm{BA}, \mathrm{m}^{2}\right)$ is obtained by multiplying this number of trees by a basal area factor (BAF), which is a function of the critical angle (Figure 2).

Figure 2: Tallying of trees in point sampling

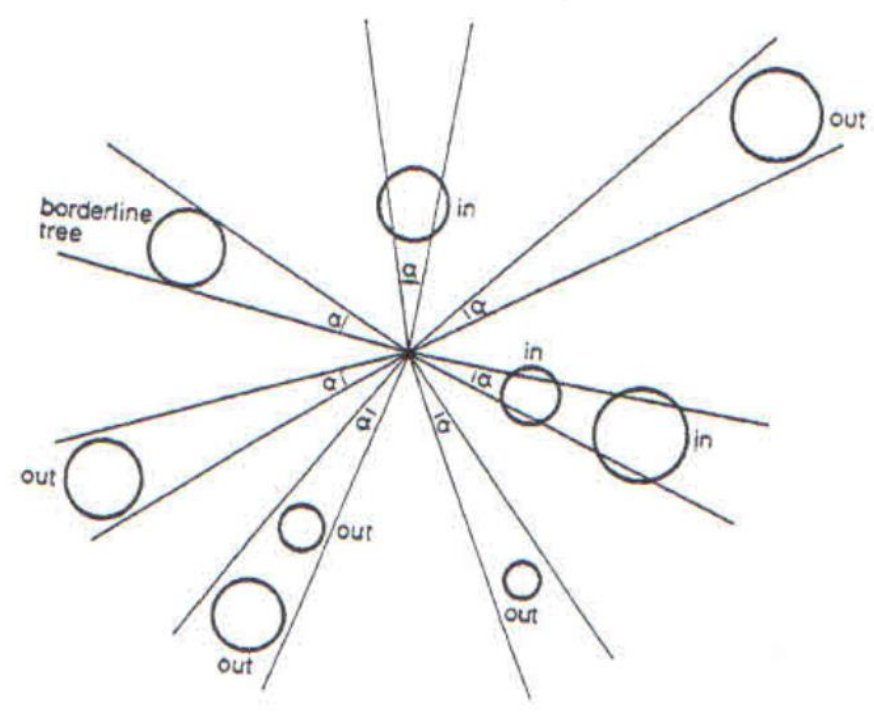

Source: Laar and Akca, 2007

The plot radius factor $c$ is calculated as follows:

Table 1

$$
c=\frac{50}{\sqrt{B A F}}
$$

The resultant $\mathrm{c}$ values for different basal area factors The resultant $\mathrm{c}$ values for different basal area factors are given below (Table 1).

\begin{tabular}{ccccc}
\hline $\begin{array}{c}\text { BAF } \\
\left(\mathbf{m}^{\mathbf{2}} \mathbf{h a}^{-1}\right)\end{array}$ & $\mathbf{1}$ & $\mathbf{2}$ & $\mathbf{3}$ & $\mathbf{4}$ \\
\hline$c$ & 50.0 & 35.4 & 28.9 & 25.0 \\
\hline
\end{tabular}


To carry out the measurements, a home-made angle gauge can be used, which consists of a $50-\mathrm{cm}$ or $1-\mathrm{m}$ long hand-held stick, with a metal blade $1 \mathrm{~cm}$ wide for the $1-\mathrm{m}$ stick being mounted on one side. The trees surrounding the sampling point were sighted at breast height $\left(\mathrm{d}_{1.3}\right)$ in a $360^{\circ}$ sweep. The tree is counted if it subtends an angle which exceeds the critical angle of the instrument. The number of sampling points per hectare varies between 5 and 10, depending on the structure and uniformity of the stands. At each stand, the height and the breast height diameter of 3 to 3 average trees are also measured and averaged. Reaveraging of the sub-averages (basal area, height, diameter) gives the approximate number of basal area per hectare $\left(\mathrm{BA}, \mathrm{m}^{2} \mathrm{ha}^{-1}\right)$. By averaging the 3-3 height and diameter at breast height data measured at the sampling plots, the values of the height (h) and the breast height diameter (d) of the average tree are obtained (Rédei et al., 2012). The simplified tree volume formula by Király (1981) can be used to calculate the mean tree volume $\left(\mathrm{m}^{3}\right): \mathrm{v}=\mathrm{qd}^{2}(\mathrm{~h}+3)$. Values of q: Common willow (Salix alba) - 0.31, Poplars (Populus spp.) - 0.34, Scots pine (Pinus sylvestris), Black locust (Robinia pseudoacacia) 0.35, Common alder (Alnus glutinosa) - 0.36, Pedunculate oak (Quercus robur) - 0.37, Turkey oak (Quercus cerris) - 0.38, European black pine (Pinus nigra) - 0.39, Norway spruce (Picea abies), Beech (Fagus sylvatica), Sessile oak (Quercus patraea) 0,40 . Primarily, the formula is applicable for $\mathrm{h}>12 \mathrm{~m}$. The stem number $(\mathrm{N}$, ha) can be calculated with the formula BA / $\mathrm{b}$, where $\mathrm{b}=\mathrm{D}_{1.3}{ }^{2} \pi 4^{-1}$. The volume per hectare of the tree stand $\left(\mathrm{m}^{3} \mathrm{ha}^{-1}\right)=\mathrm{N} \times \mathrm{v}$.

\section{RESULTS AND DISCUSSION}

Table 2 summarizes the names of the measured black locust forest compartments, the age of the tree stands, and the volume of trees per hectare determined by the two methods. The significance of the mean values of the two tree volume data sets at $\mathrm{P}=5 \%$ was examined by Student's t-distribution. The forest plan tree volume of the black locust stands included in the study was determined with yield table, which is not described here. A comparison of the two data sets reported in Table 2 is intended to prove the reliability of the ACS wood volume determination methodology. This is because this method makes it possible to determine the current wood stock with significant time and cost savings.

Table 2

Volume belonging to the two groups

\begin{tabular}{|c|c|c|c|}
\hline \multirow{2}{*}{$\begin{array}{c}\text { Location (forest } \\
\text { compartment) }\end{array}$} & \multirow[b]{2}{*}{$\begin{array}{l}\text { Age } \\
(\mathbf{y r})\end{array}$} & \multicolumn{2}{|c|}{ Volume $\left(\mathrm{m}^{3} \mathbf{h a}^{-1}\right)$} \\
\hline & & $\begin{array}{l}\text { On base of } \\
\text { forest plan }\end{array}$ & $\begin{array}{c}\text { On base of } \\
\text { ACS } \\
\end{array}$ \\
\hline Örkény 3 E & 24 & 141 & 132 \\
\hline Pusztavacs 219 A & 28 & 147 & 145 \\
\hline Üllö 6 I & 30 & 158 & 175 \\
\hline Csévharaszt $78 \mathrm{~F}$ & 31 & 224 & 192 \\
\hline Csévharaszt $62 \mathrm{~K}$ & 31 & 196 & 188 \\
\hline Pusztavacs $161 \mathrm{~A}$ & 32 & 164 & 182 \\
\hline Pusztavacs $161 \mathrm{C}$ & 32 & 168 & 162 \\
\hline Csévharaszt 7 A & 32 & 156 & 138 \\
\hline Csévharaszt $56 \mathrm{C}$ & 33 & 181 & 155 \\
\hline Kóka 1 A & 33 & 140 & 164 \\
\hline Kóka $1 \mathrm{~J}$ & 33 & 161 & 171 \\
\hline Pusztavacs $163 \mathrm{C}$ & 33 & 185 & 175 \\
\hline Pusztavacs 163 B & 33 & 188 & 177 \\
\hline Csévharaszt 18 I & 34 & 191 & 178 \\
\hline Üllö 10 D & 34 & 163 & 182 \\
\hline Csévharaszt $112 \mathrm{D}$ & 37 & 204 & 203 \\
\hline Pusztavacs $69 \mathrm{C}$ & 42 & 196 & 196 \\
\hline Pusztavacs 233 A & 44 & 299 & 300 \\
\hline Pusztavacs 94 B & 46 & 250 & 268 \\
\hline Pusztavacs $9 \mathrm{~A}$ & 47 & 270 & 288 \\
\hline
\end{tabular}

\section{CONCLUSIONS}

Angle-count sampling (ACS) is one of the simplest and fastest methods to determine volume. Although it is more or less widespread in Hungarian forest management practice, its use for primary wood production is still limited today. Our comparative studies presented that it can be advantageously used, for example, in the practice of black locust cultivation, especially in establishing the coppicing criteria of black locust stands. Other areas of application: for indirect determination of tree species composition, number of stems per hectare, yield class, industrial wood yield. This study also proves that, with due practice, the angle-count sampling can be used to determine the growing stock with relatively high accuracy compared to other forest inventory methodologies.

\section{REFERENCES}

Avery, T.E.-Burkhart, H.E. (1994): Forest Measurements. McGrawHill, Inc. pp. 408.

Barrett, J.P. (1969): Estimating averages from point-sample data. Journal of Forestry. 67:185.

Bell, J.F.-Dilworth, J.R. (1990): Log scaling and timber cruising. O.S.U. Bookstores, Inc., Corvallis, Oreg. pp. 394.

Beers, T.W.-Miller, C.I. (1964): Point sampling: Research results, theory, and applications. Purdue Univ. Agr. Expt. Sta. Res. Bull. 786. pp. 56.
Bitterlich, W. (1948): Die Winkelzahlprobe. Allgem. Forest-u, Holzw. Ztg. 59(1/2): 4-5.

Bruce, D. (1955): A new way to look at trees. Journal of Forestry. 53:163-167.

Grosenbaugh, L.R. (1958): Point sampling and line sampling: probality theory, geometric implications, synthesis. Occ.Pa No 160, S. For Exp. Stat. p. 33.

Hunt, E.V.-Baker, R.D. (1967): Practical point-sampling. SFA State College, Bull. 14. Nacogdoches, Texas. pp. 43. 
Király, L. (1981): Functioning of the Hungarian volume tables, Research report. Budapest. (In Hungarian).

Laar, A.-Akca, A. (1997): Forest Mensuration. Cuvillier Verlag, pp 418.

Laar, A.-Akca, A. (2007): Forest Mensuration. Springer, pp 385.

Oderwald, R.G. (1981): Point and plot sampling - The relationship. Journal of Forestry. 79:377-378.

Rédei, K. (1984): Yield of black locust stands (yield table of black locust 1984). FRI. Kecskemét. (In Hungarian)

Rédei, K. (2015): Coppice forestry of black locust. Agroinform publisher. Budapest. pp. 92. (In Hungarian)
Rédei, K.M.-Csiha, I.-Keserü, Zs.-Gál, J. (2012): Influence of Regeneration Method on the Yield and Stem Quality of Black Locust (Robinia pseudoacacia L.) Stands: a Case Study. Acta Silvatica et Lignaria Hungarica. Vol. 8: 103-111.

Veperdi, G. (2011): Forest mensuration, Teaching materials. Sopron. (In Hungarian).

Wensel, L.C.-Levitan, J.-Barber, K. (1980): Selection of basal area factor in point sampling. Journal of Forestry. 78: 83-84. 